\title{
Origanum Majorana Essential Oil: Some Pharmacological and Toxicological Aspects
}

\author{
Andrea dos Santos Dantas* \\ Federal University of Rio Grande do Sul, Brazil \\ *Corresponding author: Andrea dos Santos Dantas, Federal University of Rio Grande do Sul, Brazil
}

\section{ARTICLE INFO}

Received: 慧 February 01, 2019

Published: 恶 February 21, 2019

Citation: DANTAS, A.S. Origanum Majorana Essential Oil: Some Pharmacological and Toxicological Aspects. Biomed J Sci \& Tech Res 14(5)-2019. BJSTR. MS.ID.002625.

\section{ABSTRACT}

Origanum majorana essential oil has proven to be a very versatile compound with great possibilities of therapeutic application. Its potential ranges from antibacterial action to anticancer activity. However, further studies are needed to assess its toxicological activity.

Keywords: Marjoram; Essential Oil; Pharmacology; Toxicity

\section{Short Communication}

Origanum majorana L or Majorana hortensis Moench is an aromatic plant, rich in essential oils and native to the Mediterranean region, but commercially grown in southern Europe and worldwide throughout the year. It is popularly known as sweet marjoram and has been used in the form of an herbal infusion in folk medicine for asthma, cold, cough, cramps, depression, dizziness, gastrointestinal disorders, hay fever, headache, toothache, sinus congestions; as a diuretic and to promote menstruation [1,2]. Some important activities of 0 . majorana essential oil (Omeo) include antibacterial, antifungal and antioxidant actions and increased liver and kidney function $[3,4]$. Studies suggest that the oil can be used in the prevention of aging-related diseases [5-7] and central nervous system disorders $[1,8]$ because of its antioxidant effects. Previous studies have reported the potential use of 0 . majorana ethanolic extract as an anticancer agent [9], whereas the tea extract has been shown to have immunostimulant, antigenotoxic, and antimutagenic properties [2,10,11]. Furthermore, O. majorana crude extract, dichloromethane, ethyl acetate and aqueous fractions have shown antibacterial and antifungal activity [12].

Preliminary studies by Heikal [13] have suggested that coadministration of $150 \mathrm{mg} / \mathrm{kg}$ or $300 \mathrm{mg} / \mathrm{kg}$ of 0 . majorana leaf extract attenuated testicular oxidative damage and apoptosisrelated gene expression induced by methomyl exposure, which may be attributed to its antioxidant potential [13]. In another study, a lower dose $(0.16 \mathrm{~mL} / \mathrm{kg})$ of Omeo was able to prevent ethanolinduced decline in sperm quality, testosterone levels, and weight of reproductive organs in male rats [1]

The acute oral median Lethal Dose (LD50) value for Omeo in rats has been reported as $2.24 \mathrm{~g} / \mathrm{kg}$ and the acute dermal LD50 value in rabbits exceeds $5 \mathrm{~g} / \mathrm{kg}$. Furthermore, when applied at $6 \%$ in petrolatum to intact or abraded rabbit skin for $24 \mathrm{~h}$ under occlusion, Omeo was not found to be irritating [14]. A review of the literature demonstrates that terpinen-4-ol and $\gamma$-terpinene are present in Omeo at various concentrations [3,14-18], among other compounds. Terpinen-4-ol can produce toxic effects at concentrations above $1500 \mu \mathrm{L} / \mathrm{mL}$ when evaluated in vitro using a Salmonella/microsome assay [19,20]. The acute oral LD50 in rats has been reported as $3.65 \mathrm{~g} / \mathrm{kg}$ (2.71-4.59 $\mathrm{g} / \mathrm{kg}$ ) for $\gamma$-terpinene, while the acute dermal LD50 in rabbits exceeds $5 \mathrm{~g} / \mathrm{kg}$. When applied at full strength to intact or abraded rabbit skin for $24 \mathrm{~h}$ under occlusion, $\gamma$-terpinene was reported as moderately irritating [21]. Besides that, O. majorana essential oil was not able to induce in vitro gene and chromosome mutations, when evaluated in S. typhimurium and V79 Chinese hamster lung fibroblast cells, respectively. These studies contribute to more information on the toxicity of this essential oil [18]. Although investigations into the medicinal properties of plants are ongoing, the safe use of medicinal plants should be carefully evaluated. 


\section{References}

1. IM El-Ashmawy, A Saleh, OM Salama (2007) Effects of marjoram volatile oil and grape seed extract on ethanol toxicity in male rats. Basic Clin Pharmacol Toxicol 101: 320-327.

2. G Ramadan, NM El Beih, MM Zahra (2012) Egyptian sweet marjoram leaves protect against genotoxicity, immunosuppression and other complications induced by cyclophosphamide in albino rats. Br J Nutr 108(6): 1059-1068.

3. Busatta C, Vidal RS, Popiolski AS, Mossi AJ, Dariva C, et al. (2008) Application of Origanum majorana $\mathrm{L}$ essential oil as an antimicrobial agent in sausage. Food Microbiol 25(1): 207-211.

4. B Prakash, P Singh, A Kedia, NK Dubey (2012) Assessment of some essential oils as food preservatives based on antifungal, antiaflatoxin, antioxidant activities and in vivo efficacy in food system. Food Res International 49(1): 201-208.

5. WJ Jun, BK Han, KW Yu, MS Kim, IS Chang, et al. (2001) Antioxidant effects of Origanum majorana $\mathrm{L}$ on superoxide anion radicals. Food Chem 75(4): 439-444.

6. A Alizadeh, M Khosh khui, K Javidnia, OR Firuzi, SM Jokar (2011) Chemical composition of the essential oil, total phenolic content and antioxidant activity in Origanum majorana L (Lamiaceae) cultivated in Iran. Adv Environ Biol 5(8): 2326-2331.

7. MHH Roby, MA Sarhana, KAH Selima, KI Khalela (2013) Evaluation of antioxidant activity, total phenols and phenolic compounds in thyme (Thymus vulgaris L), sage (Salvia officinalis L), and marjoram (Origanum majorana L) extracts. Industrial Crops Products 43: 827-831.

8. A Rezaie, G Mousavi, M Nazeri, B Jafari, A Ebadi, et al. (2011) Comparative study of sedative, pre-anesthetic and anti-anxiety effect of Origanum majorana extract with diazepam on rats Res J Biol Sci 6: 611-614.

9. S Rao, B Timsina, VK Nadumane (2014) Evaluation of the anticancer potentials of origanum marjorana on fibrosarcoma (HT-1080) cell line. Asian Pac J Trop Dis 4: 389-394.

10. NO Al Harbi (2011) Effect of marjoram extract treatment on the cytological and biochemical changes induced by cyclophosphamide in mice. J Med Plants Res 5(23): 5479-5485.

\section{ISSN: 2574-1241}

DOI: 10.26717/BJSTR.2019.14.002625

Andrea dos Santos Dantas. Biomed J Sci \& Tech Res

This work is licensed under Creative Commons Attribution 4.0 License

Submission Link: https://biomedres.us/submit-manuscript.php
11.JA Khan, JA Jalal, C Ioanndes, SS Moselhy (2013) Impact of aqueous doash extract on urinary mutagenicity in rats exposed to heterocyclic amines. Toxicol Ind Health 29: 142-148.

12. RM Abdel Massih, A Abraham (2014) Extracts of Rosmarinus officinalis, Rheum rhaponticum and Origanum majorana exhibit significant antistaphylococcal activity. Int J Pharm Sci Res 5(3): 819-828.

13. TM Heikal (2015) Antioxidant potentials of Origanum majorana leaves extract against reproductive toxicity and apoptosis-related gene expression resulted from methomyl exposure in male rat. Planta Med 81(16).

14. R Tisserand, R Young (2014) Essential oil safety A guide for health care professionals ( $2^{\text {nd }}$ Edn) Churchill Livingstone Elsevier, London, UK, pp. 784.

15. MRA Rodrigues, EB Caramão, L Arce, A Ríos, M Valcárcel (2002) Determination of monoterpene hydrocarbons and alcohols in Majorana hortensis Moench by micellar electrokinetic capillary chromatographic. J Agric Food Chem 50(15): 4215-4220.

16. E Vági, B Simándi, Á Suhajda, É Héthelyi (2005) Essential oil composition and antimicrobial activity of Origanum majorana L extracts obtained with ethyl alcohol and supercritical carbon dioxide. Food Res International 38: 51-57.

17. S Ramos, LB Rojas, ME Lucena, G Meccia, A Usubillaga (2011) Chemical composition and antibacterial activity of Origanum majorana L essential oil from the Venezuelan Andes. J Essential Oil Res 23(5): 45-49.

18. AS Dantas, LC Klein-Júnior, MS Machado, TN Guecheva, LD Santos, et al. (2016) Origanum majorana essential oil lacks mutagenic activity in the Salmonella/microsome and micronucleus assays. Sci World J p. 7.

19. JP Fletcher, JP Cassela, D Hughes, S Cassela (2005) An evaluation of the mutagenic potential of commercially available tea tree oil in the United Kingdom. International J Aromatherapy 15(2): 81-86.

20. CB Hollenbach, RS Bing, R Stedile, FPS Mello, TL Schuch, et al. (2015) Reproductive toxicity assessment of Origanum vulgare essential oil on male Wistar rats. Acta Scientiae Veterinariae 27(80): 1-3.

21.0M Moreno (1976) $\gamma$-terpinene Report to Research Institute for Fragrance Materials, July 25, 1973 In: 1976 Food Cosmetics Toxicol 14: 875 .

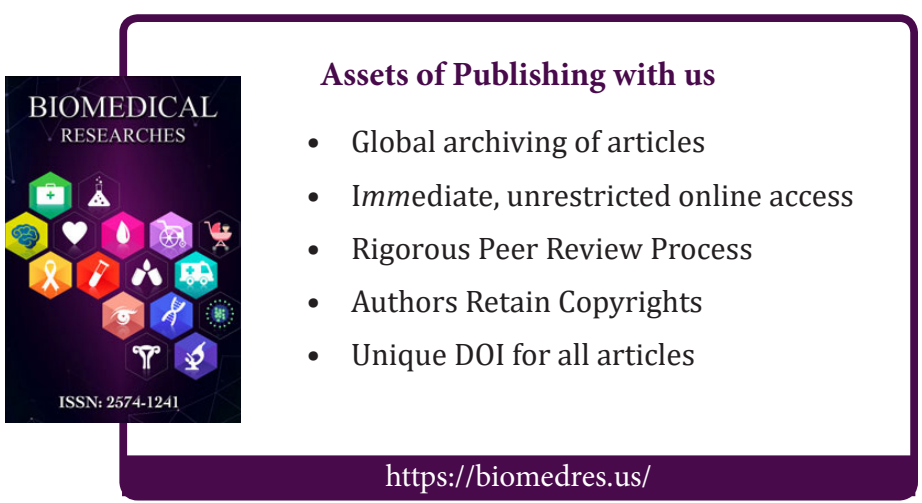

